\title{
HAKIKAT PANCASILA SEBAGAI DASAR NEGARA DAN IDEOLOGI NEGARA
}

\author{
INDRYANI SILVIA NINGSIH
}

Indryanisilvian@gmail.com

20220053

STIE AKBP PADANG

\section{A. PENDAHULUAN}

Pancasila adalah suatu ideologi yang dianut oleh bangsa Indonesia. Di dalam pancasila terdapat isi di setiap silanya sesuai dengan cita-cita, tujuan dan harapan terbentuknya negara Indonesia. Pada dasarnya Pancasila sebgai dasar sistem pemerintahan dengan cara menjalankan dan melaksanakan kegiatan yang berhubungan dengan pemerintahan dengan cara menjalankan kegiatan yang berhubungan dengan pemerintahan sesuai dengan isi pancasila tersebut.

Pancasila adalah lima nilai dasar luhur yang ada dan berkembang bersama dengan bangsa Indonesia sejak dahulu.Sejarah merupakan deretan peristiwa yang saling berhubungan. Peristiwa-peristiwa masa lampau yang berhubungan dengan kejadian masa sekarang dan semuanya bermuara pada masa yang akan datang. Hal ini berarti bahwa semua aktivitas manusia pada masa lampau berkaitan dengan kehidupan masa sekarang untuk mewujudkan masa depan yang berbeda dengan masa yang sebelumnya.

Dasar Negara merupakan alas atau fundamen yang menjadi pijakan dan mampu memberikan kekuatan kepada berdirinya sebuah Negara. Negara Indonesia dibangun juga berdasarkan pada suatu landasan atau pijakan yaitu pancasila. Pancasila, dalam fungsinya sebagai dasar Negara, merupakan sumber kaidah hukum yang mengatur Negara Republik Indonesia, termasuk di dalamnya seluruh unsur-unsurnya yakni pemerintah, wilayah, dan rakyat. Pancasila dalam kedudukannya merupakan dasar pijakan penyelenggaraan Negara dan seluruh kehidupan Negara Republik Indonesia.

Pancasila adalah pedoman kehidupan berbangsa dan bernegara bagi seluruh rakyat Indonesia. Sepanjang Indonesia masih ada, pancasila akan menyertai perjalannya. Nilai-nilai esensial yang terkandung dalam pancasila, yaitu : Ketuhanan, Kemanusiaan, Persatuan, Kerakyatan serta Keadilan. Tanggal 1 Juni 1945 adalah lahirnya pancasila dari pidato Ir. Soekarno di hadapan para anggota Badan Penyelidik Usaha-Usaha Persiapan Kemerdekaan Indonesia (BPUPKI). Pancasila adalah filsafat negara Republik Indonesia yang secara resmi disahkan oleh PPKI pada tanggal 18 Agustus 1945 dan tercantum dalam pembukaan UUD 1945 yang diundangkan dalam berita Republik Indonesia tahun II No. 7 bersamaan dengan batang tubuh UUD 1945. 


\section{B. PEMBAHASAN}

Pancasila - Setiap negara di dunia ini mempunyai dasar negara yang dijadikan landasan dalam menyelenggarakan pemerintah negara. Seperti Indonesia, Pancasila dijadikan sebagai dasar negara atau ideologi negara untuk mengatur penyelenggaraan negara. Hal tersebut sesuai dengan bunyi pembukaan UUD 1945 alenia ke-4 yang berbunyi : "Maka disusunlah kemerdekaan kebangsaan Indonesia itu dalam suatu UUD negara Indonesia yang berbentuk dalam suatu susunan negara".

Dengan demikian kedudukan pancasila sebagai dasar negara termaktub secara yuridis konstitusional dalam pembukaan UUD 1945, yang merupakan cita - cita hukum dan norma hukum yang menguasai hukum dasar negara RI dan dituangkan dalam pasal - pasal UUD 1945 dan diatur dalam peraturan perundangan. Selain bersifat yuridis konstitusional, pancasila juga bersifat yuridis ketata negaraan yang artinya pancasila sebagai dasar negara, pada hakikatnya adalah sebagai sumber dari segala sumber hukum. Artinya segala peraturan perundangan secara material harus berdasar dan bersumber pada pancasila. Apabila ada peraturan (termasuk di dalamnya UUD 1945) yang bertentangan dengan nilai - nilai luhur pancasila, maka sudah sepatutnya peraturan tersebut dicabut.

Berdasarkan uraian tersebut pancasila sebagai dasar negara mempunyai sifat imperatif atau memaksa, artinya mengikat dan memaksa setiap warga negara untuk tunduk kepada pancasila dan bagi siapa saja yang melakukan pelanggaran harus ditindak sesuai hukum yang berlaku di Indonesia serta bagi pelanggar dikenakan sanksi - sanksi hukum.

Nilai - nilai luhur yang terkandung dalam pancasila memiliki sifat obyektif - subyektif. Sifat subyektif maksudnya pancasila merupakan hasil perenungan dan pemikiran bangsa Indonesia, sedangkan bersifat obyektif artinya nilai pancasila sesuai dengan kenyataan dan bersifat universal yang diterima oleh bangsa - bangsa beradab. Oleh karena memiliki nilai obyektif - universal dan diyakini kebenarannya oleh seluruh bangsa Indonesia maka pancasila selalu dipertahankan sebagai dasar negara. Jadi berdasarkan uraian tersebut di atas maka dapat disimpulkan bahwa pancasila sebagai dasar negara memiliki peranan yang sangat penting dalam mengatur kehidupan berbangsa dan bernegara sehingga cita - cita para pendiri bangsa Indonesi dapat terwujud.

Bagi bangsa indonesia hakikat yang sesungguhnya dari pancasila adalah sebagai pandangan hidup bangsa dan sebagai dasar negara. Kedua pengertian tersebut sudah selayaknya kita pahami akan hakikatnya.

Selain dari pengertian tersebut, pancasila memiliki beberapa sebutan berbeda, seperti :

- Pancasila sebagai jiwa negara,

- Pancasila sebagai kepribadian bangsa,

- Pancasila sebagai sumber dari segala sumber hukum,dll.

Walaupun begitu, banyaknya sebutan untuk pancasila bukanlah merupakan suatu kesalahan atau pelanggaran melainkan dapat di jadikan sebagai suatu kekayaan akan makna dari pancasila bagi bangsa indonesia. Karena hal yang terpenting adalah perbedaan penyebutan itu tidak mengaburkan hakikat pancasila yang sesungguhnya yaitu sebagai dasar negara. Tetapi pengertian pancasila tidak dapat di tafsirkan oleh sembarangan orang karena akan dapat mengaturkan maknanya dan pada akhirnya merongrong dasar negara. 


\section{PANCASILA SEBAGAI DASAR NEGARA}

Pancasila dalam kedudukanya ini sering disebut sebagai dasar filsafat atau dasar falsafah negara (Philosofische Gronslag) dari Negara, ideologi negara atau Statsidee, dalam pengertian ini pancasila merupakan dasar nilai serta untuk mengatur pemerintahan negara atau dengan kata lain perkataan. Konsekuensinya seluruh pelaksanaan dan penyelenggara Negara terutama segala peraturan perundang-undangan termasuk proses reformasi dalam segala bidang dewasa ini dijabarkan dan diderivasikan dari nilai-nilai pancasila. Maka pancasila merupakan sumber dari segala sumber hukum, pancasila merupakan sumber kaidah hukum negara yang secara konstitusional mengatur negara Republik Indonesia beserta seluruh unsur-unsurnya yaitu rakyat wilayah, beserta Negara.

Sebagai dasar Negara, Pancasila merupakan suatu asas kerokhanian yang meliputi suasana kebatinan atau cita-cita hukum, sehingga merupakan suatu sumber nilai, norma serta kaidah, baik moral maupun hukum negara, dan menguasai dasar baik yang tertulis atau Undang-Undang Dasar maupun yang tidak tertulis atau dalam kedudukannya sebagai dasar negara, pancasila mempunyai kekuatan mengingat secara hukum. Sebagai sumber dari segala hukum atau sumber tertib hukum Indonesia maka pancasila tercantum dalam ketentuan tertinggi yaitu pembukaan UUD 1945.

Kemudian dijelmakan atau dijabarkan lebih lanjut dalam pokok-pokok pikiran, yang meliputi suasana kebatinan dari UUD 1945, yang pada akhirnya dikongritiskan atau dijabarkan lebih lanjut dalam pokok-pokok pikiran, yang meliputi suasana kebatinan dari UUD 1945, yang pada akhirnya dikongritiskan atau dijabarkan dari UUD 1945 serta hukum positif lainya, kedudukan pancasila sebagai dasar negara tersebut dapat dirincikan sebagai berikut: Pancasila sebagai dasar negara adalah sumber dari segala sumber hukum (sumber tertib hukum) Indonesia. Dengan demikian pancasila merupakan asas kerohanian tertib hukum Indonesia yang dalam pembukaan UUD 1945 dijelmakan lebih lanjut ke dalam empat pokok pikiran. Meliputi suasana kebatinan (Geistlichenhintergrud) dari UUD 1945.

Mewujudkan cita-cita hukum bagi hukum dasar negara (baik hukum yang tertulis maupun tidak tertulis). Mengandung norma yang mengharuskan undang-undang dasar mengandung isi yang mewajibkan pemerintah dan lain-lain penyelenggara negara (termasuk penyelenggara partai dan golongan fungsional). Memegang teguh cita-cita moral rakyat yang luhur. Hal ini dapat dipahami karena semangat adalah penting bagi pelaksanaan dan penyelenggara negara, karena masyarakat dan negara indonesia senantiasa tumbuh dan berkembang seiring dengan perkembangan zaman dan dinamika masyarakat dan negara akan tetap diliputi dan diarahkan asas kerohanian negara.

Dasar formal kedudukan pancasila dasar Negara Republik Indonesia tersimpul dalam pembukaan UUD 1945 alinea IV yang berbunyi sebagai berikut:" maka disusunlah kemerdekaan kebangsaan indonesia itu dalam suatu Undang-Undang Dasar Negara Indonesia yang terbentuk dalam suatu susunan negara Republik Indonesia yang berkedaulatan rakyat, yang berdasarkan Ketuhanan Yang Maha Esa, kemanusiaan yang adil dan beradab, persatuan Indonesia, kerakyatan yang dipimpin oleh hikmat kebijaksanaan permusyawaratan/perwakilan, serta dengan mewujudkan suatu keadilan sosial seluruh rakyat indonesia". Pengertian kata" Dengan Berdasarkan Kepada" Hal ini secara yuridis memiliki makna sebagai dasar negara.

\section{Hakikat Pancasila Sebagai Dasar Negara dan Ideologi Negara Secara Terperinci}

Walaupun dalam kalimat terakhir pembukaan UUD 1945 tidak tercantum kata 'pancasila' secara eksplisit namun anak kalimat " dengan berdasar kepada" ini memiliki makna dasar negara adalah pancasila. Hal ini didasarkan atas interpretasi historis sebagaimana ditentukan oleh BPUPKI bahwa dasar negara Indonesia itu disebut dengan istila pancasila. Sebagaimana telah ditentukan oleh pembentukan negara bahwa tujuan utama dirumuskannya pancasila adalah sebagai dasar negara 
Republik Indonesia. Oleh karena itu fungsi pokok pancasila adalah sebagai dasar Negara Republik Indonesia.

Hal ini sesuai dengan dasar yuridis sebagaimana tercantum dalam pembukaan UUD 1945, ketetapan No. XX/MPRS/1966. (Jo ketetapan MPR No. V/MPR/1973 dan ketetapan No. IX/MPR/1978).

Dijelaskan bahwa pancasila sebagai sumber dari segala sumber hukum atau sumber tertib hukum indonesia yang ada pada hakikatnya adalah merupakan suatu pandangan hidup, kesadaran dan cita-cita hukum serta cita-cita moral yang meliputi suasana kebatinan serta dari bangsa indonesia. Selanjutnya dikatakan bahwa cita-cita mengenai kemerdekaan individu, kemerdekaan bangsa prikemanusiaan, keadilan sosial, perdamaian nasional, cita-cita politik mengenai sifat, bentuk dan tujuan negara, citacita moral mengenai kehidupan kemasyarakatan dan keagamaan sebagai pengejawatan dari budi nurani manusia.

Dalam proses reformasi dewasa ini MPR melaui sidang istimewa tahun 1998, mengembalikan kedudukan pancasila sebagai dasar Negara Republik Indonesia yang tertuang dalam Tap. No. XVIII/MPR/1998. Oleh karena itu segala agenda dalam proses reformasi, meliputi berbagai bidang lain mendasarkan pada kenyataan aspirasi rakyat (Sila 1V) juga harus mendasarkan nilai-nilai yang terkandung dalam pancasila.

\section{PANCASILA SEBAGAI IDEOLOGI BANGSA DAN NEGARA}

a) Pancasila sebagai ideologi bangsa.

Pancasila sebagai ideologi bangsa adalah pancasila sebagai cita-cita negara atau cita-cita yang menjadi basis bagi suatu teori atau sistem kenegaraan untuk seluruh rakyat dan bangsa Indonesia. Berdasarkan Tap. MPR No. XVIII/MPR/1998 tentang pencabutan ketetapan MPR tentang P4. Ditegaskan bahwa pancasila adalah dasar NKRI yang harus dilaksanakan secara konsisten dalam kehidupan berbangsa dan bernegara.

b) Pancasila sebagai ideologi negara.

Pengertian ideologi-ideologi berasal dari bahasa yunani yaitu iden yang berarti melihat, atau idea yang berarti raut muka, perawakan, gagasan buah pikiran dan kata logi yang berarti ajaran, dengan demikian ideologi adalah ajaran atau ilmu tentang gagasan dan buah pikiran atau science des ideas (Marsudi, 2001).

Puspowardoyo (1992) menyebutkan bahwa ideologi dapat di rumuskan sebagai kompleks pengetahuan dan nilai secara keseluruhan menjadi landasan seseorang atau masyarakat untuk memahami jagat raya dan bumi seisinya, serta menentukan sikap dasar untuk mengolahnya. Berdasarkan pemahaman yang dihayatinya seseorang dapat menangkap apa yang dilihat benar dan tidak benar serta apa yang dinilai baik dan tidak baik.

Menurut pendapat Harol H.Titus defenisi dari ideologi adalah suatu istilah yang digunakan untuk sekelompok cita-cita mengenai berbagai macam masalah politik ekonomi filsafat sosial yang sering dilaksanakan bagi suatu rencana yang sistematis tentang suatu cita-cita yang dijalankan oleh sekelompok atau lapisan masyarakat.

1. Ciri-ciri ideologi adalah sebagai berikut :

a. Mempunyai derajat yang tertinggi sebagai nilai hidup kebangsaan dan kenegaraan

b. Mewujudkan suatu asaz kerohanian, pandangan-pandangan hidup, pegangan hidup yang dipelihara diamalkan, dilestarikan kepada generasi berikutnya, diperjuangkan dan dipertahankan dengan kesediaan berkorban. 
2. Fungsi ideologi menurut pakar dibidangnya :

a. Sebagai sarana untuk memformulasikan dan mengisi kehidupan manusia secara individual (cahyono,1986).

b. Sebagai jembatan pergeseran kendali kekuasaan dari generasi tua dengan generasi muda, (setiardja,2001).

c. Sebagai kekuatan yang mampu memberi semangat dan motivasi individu, masyarakat,dan bangsa untuk menjalani kehidupan dalam mencapai tujuan. (hidayat,2001).

3. PANCASILA SEBAGAI IDEOLOGI TERBUKA DAN TERTUTUP

Pancasila sebagai ideologi terbuka adalah sebagai suatu sistem pemikiran terbuka. Ciri-ciri ideologi terbuka dan ideologi tertutup adalah:

a. Ideologi Terbuka

1. Merupakan cita-cita yang sudah hidup dalam masyarakat

2. Berupa nilai-nilai dan cita-cita yang berasal dari dalam masyarakat sendiri.

3. Hasil musyawarah dan konsesus masyarakat.

4. Bersifat dinamis dan reformasi.

b. Ideologi Tertutup

1. Bukan merupakan cita-cita yang sudah hidup dalam masyarakat,

2. Bukan berupa nilai dan cita-cita

3. Kepercayaan dan kesetian ideologis yang kaku

4. Terdiri atas tuntutan kongkrit dan operational yang diajukan secara mutlak

Nilai - nilai yang terkandung dalam ideologi pancasila sebagai ideologi terbuka:

1. Nilai dasar, yaitu hakekat kelima sila Pancasila

2. Nilai instrumental, yang merupakan arahan, kebijakan strategi, sasaran serta lembaga pelaksanaannya

3. Nilai praktis, yaitu merupakan realisasi nilai-nilai instrumental dalam suatu realisasi pengalaman yang bersipat nyata, dalam kehidupan sehari-hari dalam masyarakat,berbangsa dan bernegara.

\section{PENUTUP}

Pancasila merupakan produk otentik pendiri negara pancasila. Nilai nilai pancasila bersumber dan digali dari nilai agama, kebudayaan dan adat istiadat. Pancasila merupakan pandangan hidup bangsa dan filsafat kenegaraan. Betapapun lemahnya pemerintahan suatu rezim, tetapi pancasila tetap bertahan dalam kehidupan berbangsa dan bernegara. Betapapun ada upaya untuk mengganti pancasila sebagai ideologi bangsa, tetapi terbukti pancasila merupakan pilihan yang terbaik bagi bangsa indonesia. Pancasila merupakan pilihan terbaik bagi bangsa indonesia karena bersumber dandigali dari nilai - nilai agama, adat istiadat dan kebudayaan, dan adat istiadat yang hidup dan berkembang di bumi indonesia. 


\section{DAFTAR PUSTAKA}

Darmini Roza dan Laurensius Arliman S Peran Pemerintah Daerah Di Dalam Melindungi Hak Anak

Di Indonesia, Masalah-Masalah Hukum, Volume 47, Nomor 1, 2018.

Laurensius Arliman S, Komnas HAM dan Perlindungan Anak Pelaku Tindak Pidana, Deepublish, Yogyakarta, 2015.

Laurensius Arliman S, Penguatan Perlindungan Anak Dari Tindakan Human Trafficking Di Daerah Perbatasan Indonesia, Jurnal Selat, Volume 4, Nomor 1, 2016.

Laurensius Arliman S, Problematika Dan Solusi Pemenuhan Perlindungan Hak Anak Sebagai

Tersangka Tindak Pidana Di Satlantas Polresta Pariaman, Justicia Islamica, Volume 13, Nomor 2, 2016.

Laurensius Arliman S, Pelaksanaan Perlindungan Anak Yang Tereksploitasi Secara Ekonomi Oleh Pemerintah Kota Padang, Veritas et Justitia, Volume 2, Nomor 1, 2016.

Laurensius Arliman S, Kedudukan Ketetapan MPR Dalam Hierarki Peraturan Perundang-Undangan Di Indonesia, Lex Jurnalica, Volume 13, Nomor 3, 2016.

Laurensius Arliman S, Komnas Perempuan Sebagai State Auxialiary Bodies Dalam Penegakan Ham Perempuan Indonesia, Justicia Islamica, Volume 14, Nomor 2, 2017.

Laurensius Arliman S, Peranan Pers Untuk Mewujudkan Perlindungan Anak Berkelanjutan Di Indonesia, Jurnal Ilmu Hukum Tambun Bungai, Volume 2, Nomor 2, 2017.

Laurensius Arliman S, Mewujudkan Penegakan Hukum Yang Baik Untuk Mewujudkan Indonesia Sebagai Negara Hukum, Jurnal Hukum Doctrinal, Volume 2, Nomor 2, 2017.

Laurensius Arliman S, Participation Non-Governmental Organization In Protecting Child Rights In The Area Of Social Conflict, The 1st Ushuluddin and Islamic Thought International Conference (Usicon), Volume 1, 2017.

Laurensius Arliman S, Partisipasi Masyarakat Dalam Pembentukan Perundang Undangan Untuk Mewujudkan Negara Kesejahteraan Indonesia, Jurnal Politik Pemerintahan Dharma Praja, Volume 10, Nomor 1, 2017, https://doi.org/10.33701/jppdp.v10i1.379.

Laurensius Arliman S, Peran Komisi Perlindungan Anak Indonesia Untuk Mewujudkan Perlindungan Anak, Jurnal Respublica Volume 17, Nomor 2, 2018.

Laurensius Arliman S, Menjerat Pelaku Penyuruh Pengrusakan Barang Milik Orang Lain Dengan Mempertimbangkan Asas Fungsi Sosial, Jurnal Gagasan Hukum, Volume 1, Nomor 1, 2019.

Laurensius Arliman S, Ilmu Perundang-Undangan Yang Baik Untuk Negara Indonesia, Deepublish, Yogyakarta, 2019.

Laurensius Arliman S, Isdal Veri, Gustiwarni, Elfitrayenti, Ade Sakurawati, Yasri, Pengaruh Karakteristik Individu, Perlindungan Hak Perempuan Terhadap Kualitas Pelayanan Komnas Perempuan Dengan Kompetensi Sumber Daya Manusia Sebagai Variabel Mediasi, Jurnal Menara Ekonomi: Penelitian dan Kajian Ilmiah Bidang Ekonomi, Volume 6, Nomor 2, 2020. 
Laurensius Arliman S, Pendidikan Kewarganegaraan, Deepublish, Yogyakarta, 2020.

Laurensius Arliman S, Makna Keuangan Negara Dalam Pasal Pasal 23 E Undang-Undang Dasar 1945, Jurnal Lex Librum, Volume 6, Nomor 2 Juni 2020, http://dx.doi.org/10.46839/11jih.v6i2.151.

Laurensius Arliman S, Kedudukan Lembaga Negara Independen Di Indonesia Untuk Mencapai Tujuan Negara Hukum, Kertha Semaya Journal Ilmu Hukum, Volume 8, Nomor 7, 2020.

Laurensius Arliman S, Pelaksanaan Assesment Oleh Polres Kepulauan Mentawai Sebagai Bentuk Pelaksanaan Rehabilitasi Bagi Pecandu Dan Korban Penyalahgunaan Narkotika, Jurnal Muhakkamah, Volume 5, Nomor 1, 2020.

Laurensius Arliman S, Aswandi Aswandi, Firgi Nurdiansyah, Laxmy Defilah, Nova Sari Yudistia, Ni Putu Eka, Viona Putri, Zakia Zakia, Ernita Arief, Prinsip, Mekanisme Dan Bentuk Pelayanan Informasi Kepada Publik Oleh Direktorat Jenderal Pajak, Volume 17, No Nomor, 2020.

Larensius Arliman S, Koordinasi PT. Pegadaian (Persero) Dengan Direktorat Reserse Narkoba Polda Sumbar Dalam Penimbangan Barang Bukti Penyalahgunaan Narkotika, UIR Law Review, Volume 4, Nomor 2, 2020, https://doi.org/10.25299/uirlrev.2020.vol4(1).3779.

Laurensius Arliman S, Tantangan Pendidikan Kewarganegaraan Pada Revolusi 4.0, Ensiklopedia Sosial Review, Volume 2, Nomor 3, 2020.

Muhammad Afif dan Laurensius Arliman S, Protection Of Children's Rights Of The Islamic And Constitutional Law Perspective Of The Republic Of Indonesia, Proceeding: Internasional Conference On Humanity, Law And Sharia (Ichlash), Volume 1, Nomor 2, 2020.

Otong Rosadi danLaurensius Arliman S, Urgensi Pengaturan Badan Pembinaan Idelogi Pancasila Berdasarkan Undang-Undang Sebagai State Auxiliary Bodies yang Merawat Pancasila dalam Perspektif Hak Asasi Manusia, Prosiding Konferensi Nasional Hak Asasi Manusia, Kebudayaan dan Tujuan Pembangunan Berkelanjutan Indonesia pada Masa Pandemi Covid-19: Tantangan untuk Keilmuan Hukum dan Sosial Volume 1, Universitas Pancasila, Jakarta, 2020. 